\title{
12 Eylül Darbe Dönemini Anlatan Romanlarda Baskın Bir Ruh Hali Olarak Bungunluk *
}

\author{
Depression As A Dominant Mood in The Novels Describing The September 12 Coup Period
}

\author{
Erdal AÇIKYOL \\ ${ }^{a}$ Doktora Öğrencisi, Dicle Üniversitesi, \\ Diyarbakır, Türkiye, \\ erdalyol1984@gmail.com, ORCID: \\ 0000-0002-9412-8085
}

\begin{abstract}
ÖZ
Bu çalışmada, 12 Eylül Askeri Darbe atmosferini yansıtan Orhan Pamuk'un Sessiz Ev, Latife Tekin'in Gece Dersleri ve Ayşegül Devecioğlu'nun Kuş Diline Öykünen romanlarından yola çıkılarak dönemin bireylerinde yoğun şekilde yaşanan bungunluğa (can sıkıntısı) değinilmiştir. İlk başta, içe çekilimin önemli eğilimlerinden olan iç sıkıntı halinin ne olduğu, durumsal ve varoluşsal olarak sınıflara ayrılış gerekçeleri ve iç dünyada yol açtığı neticelere değinilmiş; daha sonra roman analizlerime geçilmiştir. Tinsel daralmanın anlatı karakterleri üzerinde baskın bir psikolojik izlek haline gelmesine yol açan gerekçelere odaklanılarak bu negatif yönelimin hangi koşullarda palazlandığına dair tespitlerde bulunulmuştur. Her üç eser de bu açıdan somut veriler sağladığından işlevsel konuma sahiptir. Romanlardaki vakaların ilerlemesinde önemli görev edinen karakterler, hem sözleriyle ham de davranışlarıyla içe burkulma eğilimlerinden biri olan ruhsal daralmayı belirgin tarzda duyumsar. Çalışmada, aynı zamanda dönemin siyasi ve toplumsal gelişmelerine de kısaca değinilerek darbe öncesi ve sonrasına dair genel bir görünüm çizilmiştir. Böylece ferdin kapıldığı can sıkıntısının sosyo-politik konjonktürle sıkı bağ içinde olduğu gösterilmeye çalışılmıştır.
\end{abstract}

Anahtar kelimeler: Can sıkıntısı, 12 Eylül Darbesi, Roman.

\begin{abstract}
In this study, boredom heavily seen in individuals of the period has been mentioned in the novels of period including Sessiz Ev, Latife Tekin'in Gece Dersleri and Ayşegül Devecioğlunun Kuş Diline Öykünen by Orhan Pamuk which all reflect the atmosphere of 12 September Military Coup. First of all, reasons of separation into classes which are situational and existential, and consequences in the inner world; afterwards, it is continued with my analysis of the novel. It has been determined under which conditions this negative orientation grows up by focusing reasons leading to a dominant psychological theme on the narrative characters of mental breakdown. It has been a functional position because all three works provide concrete data from this point. Characters playing an important role in the progress of the cases in the novels feel mental construction, which is one of the tendencies to become introverted both with their words and with their actions. Also in this study, a general view of the before and after the coup has been drawn by briefly mentioning the political and social developments of the period. Thus, it has been tried to show that the boredom of the individual is in close connection with socio-political conjecture.
\end{abstract}

Keywords: Boredom, September 12 Coup, Novel.

\footnotetext{
* Bu makalede bilimsel araştırma ve yayın etiği ilkelerine uyulmuştur. / In this article, the principles of scientific research and publication ethics were followed.

* “Servet-i Fünûn ve 12 Eylül Darbe Dönemi’ni Anlatan Romanlarda İçe Burkulma Eğilimleri” başlıklı yayınlanmamış doktora tezimden derlenmiştir.

Atıf-Reference: Açıkyol, E. (2021). 12 Eylül Darbe Dönemini Anlatan Romanlarda Baskın Bir Ruh Hali Olarak Bungunluk. Bitlis Eren Üniversitesi Sosyal Bilimler Dergisi, 10 (2), 38-44.
} 


\section{GİRIŞ}

12 Eylül Darbesi, Genelkurmay Başkanı Kenan Evren liderliğinde Türk Silahlı Kuvvetleri tarafından emir-komuta hiyerarşisi içinde gerçekleşen yıkıcı nitelikte bir girişimdir. Darbenin en önemli sebebi, sağ-sol arasındaki şiddetin meşru hükümetler tarafından önlenemez hale gelmesidir. Gruplar arasındaki çatışmanın teorik altyapısı, 1961 Anayasası'nın kabul etmiş olduğu fikir hürriyetine kadar uzanır. Bu anayasanın benimsediği ifade özgürlüğü, hem solun hem de sağın gelişim aşamalarını tamamlamasında önemli bir işlev taşır. 60’lı yıllar boyunca anayasanın vermiş olduğu örgütlenme özgürlüğüne dayanarak geniş bir alana yayılan her iki kesim, 1968 tarihi itibariyle birbirlerine dönük şiddete başvurmaya başlar. Yalnız sağ-sol kavgasından önce, solun güvenlik güçleriyle çatışmaya girdiği görülür:

Siyasal şiddet kuşkusuz, 1960'ların sonlarında solcu gruplar tarafından başlatıldı. Amerika'nın Altıncı Filosu'nun Temmuz 1968 ve Şubat 1968'deki gelişleri sırasında polis ve askerle şiddetli çarpışmalar gerçekleşti, ölenler oldu. Ancak soldaki şiddet, 1968 sonlarından itibaren ve 1969-1970 yıllarında daha da artarak militan sağdan, bilhassa Türkeş’in Bozkurt'larından gelen şiddetle karşılaştı ve militan sağın şiddeti çok daha baskın hale geldi (Zürcher, 2018: 295).

Sol ve sağ gruplar arasındaki şiddetin pratik zeminini oluşturan olay ise ülke dışından kaynaklanır. 1968'de Fransa'nın başkenti Paris’te üniversiteli öğrenciler tarafından başlayan protestolar, kısa bir süre içinde tüm dünyaya yayılır. "Daha fazla özgürlük, eşitlik, adalet ve temiz bir çevre" (Bulut, 2011: 127) talebiyle hareket eden gençler, statükocu düzenlerin dayatmalarına karşı ayaklanır. Türkiye'de de çok kısa bir süre içinde etkisini hissettiren bu gösteriler, sol menşeli yapıların eylemleri için can simidi fonksiyonu taşır. Tıpkı Fransa'da olduğu gibi Türkiye'deki eylemleri de üniversiteli öğrenciler başlatır ve bu öğrenciler ilk başlarda açık şekilde herhangi bir politik talepte bulunmaz. Gençleri harekete geçiren ana saik, üniversitelerde eğitimle ilgili reform talebidir. "Türkiye'de 1967-1968 y1llarındaki ilk boykot ve işgal hareketlerinin belirgin niteliği, üniversite içi sorunlar ve genel olarak eğitim sistemiyle ilgili oluşlarıdır” (Kışlalı, 1974: 51). Eğitimle ilgili başlayan yenilik talepleri, kısa bir süre sonra siyasal kimliğe bürünür ve şiddet eylemlerinin ortaya çıkmasına yol açar.

Bir yandan 1961 Anayasası'nın temel hak ve hürriyetlere getirmiş olduğu özgürlükler, diğer yandan Fransa merkezli 68 kuşağının isyancı tutumu sonucu başlayan şiddet vakaları, 1968-1971 zaman aralığında toplumsal sahada kargaşaya yol açar. Üç yıl boyunca aralıksız devam eden çatışmaların ülkeyi kaosa sürüklediğini iddia eden Türk Silahlı Kuvvetleri, 12 Mart 1971 yılında emir-komuta zinciri içindeki ilk darbesini gerçekleştirir. Fakat bu darbe, şiddeti sonlandırmak bir yana onun dozajını daha da arttırır. Gruplar arasında başlayan saha egemenliği mücadelesi sokak, kampüs gibi dar mekânlardan çıkarak mahalle, bölge gibi geniş alanlara doğru bir seyir izler. Öbekler, egemenlik kurdukları yerleri kurtarılmış bölge ilan ederek güç gösterisinde bulunur. Ülke içi şiddet olaylarını bastırmak amacıyla 26 Aralık 1978'de bazı şehirlerde başlayan sıkıyönetim uygulamaları da var olan yangını söndüremez. Bir yandan örgütler arası şiddet, diğer yandan güvenlik güçleriyle gruplar arası çatışmalar önüne geçilmez boyutlara varır. Toplumun tüm alanlarında etkisini hissettiren bu kaotik ortam, 12 Eylül'de gerçekleşen darbeyle nihai bir sessizliğe bürünür.

12 Eylül 1980 tarihinde darbe yapan Silahlı Kuvvetler, 1983 yılının kasım ayında yapılan genel seçimlere kadar ülkeyi yöneten siyasi erk olur. Kenan Evren başkanlığında kurulan ve darbeye yol açan Milli Güvenlik Konseyi, iktidarda olduğu bu süre zarfında muhalif kesimlere dönük sert politikaları uygulama sahasına geçirir. Darbenin akabinde başlayan insan avıyla farklı gruplara mensup kesimlere dönük yıldırma operasyonu başlatılır. Milli Güvenlik Konseyi, bir yandan militanlardan sempatizanlara kadar sol ve sağ fraksiyonlar üzerinde devletin kıyıcı elini gösterirken diğer yandan siyasi mekanizmaları ve sivil toplum kuruluşlarını saf dışı bırakır. "Milli Güvenlik Konseyi anayasayı askıya alan, parlamentoyu dağıtan, siyasal partileri kapatan, parti önderlerini tutuklayan ve neredeyse bütün meslek kuruluşlarıyla sendika konfederasyonlarının faaliyetlerini askıya alan kararnameler” (Ahmad, 2017: 215-216) çıkarır. Ordunun ülkeyi bütünüyle tekeline aldığı bu dönem, 6 Eylül 1987’de yapılan halk oylamasıyla nihayete erer. 12 Eylül Darbesi’yle politik faaliyette bulunmaları yasaklanan siyasi liderler, bu referandum sayesinde tekrar siyaset sahnesinde yerlerini almaya başlar. Bununla birlikte yine aynı yıl içerisinde sıkıyönetim uygulamaları da tamamen kaldırılır. Darbenin gerçekleşmesinden önce sınırlı sayıda şehirde başlayıp darbeden sonra Türkiye'nin tamamına yayılan sıkıyönetim sisteminin kademeli olarak kaldırılması, temel hak ve hürriyetler noktasında kayda değer bir adım olur.

\section{BİR İÇE ÇEKİLME YÖNELIMİ: BUNGUNLUK}

Günlük yaşamda çok sık karşılaşılan eğilimlerden biri olan bungunluk (can sıkıntısı), insanoğlunun en önemli duygusal tecrübelerinden biridir. Küçük yaştaki çocuklardan yaşlılara kadar toplumun tüm kesimleri üzerinde bazen geçici bazen de kalıcı olarak etkisini hissettiren bu duygu, bireyde hafif tiksinti duygusu yaratarak onun günlük yaşama aktif katılımını olumsuz yönde etkiler. Ferdin hem kendi beniyle hem de toplumla sağlıklı bir ilişki inşa etmesinin önünde engel olarak duran iç sıkıntı, kendi içinde durumsal(basit) ve varoluşsal olmak üzere iki başlık altında ele alınır. Basit iç daralma hali, kısa süre içinde etkisini yitirmesine karşın varoluşsal bungunluk tipi uzun bir süre varlığını devam ettirir.

Basit can sıkıntısı bir ruh hali değildir. Uzun zaman boyunca hissedilmesi gerekmez. Basit can sıkıntısı her an, hızlıca ortaya çıkabilir ama hapsedilmesi veya tekrarı yaratan kaynak ortadan kaldırıldığında birden yok olur. Diğer yandan varoluşsal can sıkıntısı, karşı karşıya kalınan şey bir ruh haline dönüşene kadar ısrarcı bir diş ağrısı gibi tekrar ortaya çıkar (Toothey, 2014: 33).

Gündelik, geçici bir özelliğe sahip olan durumsal iç sıkıntı, yaşam sathında çözüme sahip olmasından ötürü bireyin ruh dünyasında ciddi düzeyde bir tahribat oluşturmaz. Hayatın mânâ yitimine uğraması sonucu ortaya çıkan varoluşsal can sıkıntısı 
ise kalıcı niteliğe sahiptir. Yaşama anlam verememe, ölümün olduğu yerde hayatın anlamsız oluşuna inanma gibi metafizik içerikli zihinsel sorgulamalar bu can sıkıntısı çeşidinin ruhsal açıdan yıpratıcı özelliğe ve süreklilik arz eden bir yapıya haiz olduğunu gösterir. Bunun yanı sıra sıradan bungunluk kendisini dış bulgularla görünür hale getirirken varoluşsal huzursuzluk, mümkün mertebe varlığını gizleme yoluna başvurur. "Durumsal sıkıntı esnemelerle, sabırsız hareketlerle, kol ve bacak kasılmalarıyla vs. belli olurken; daha derin olan varoluşsal sıkıntı, kendisini dış belirtilerle göstermez- ya da çok az gösterir" (Svendsen, 2020: 52). Zaman aralığının kısalığı ya da uzunluğu, dil dışı göstergelerle ortaya çıkan fiziksel tepkiler gibi farklılıklara rağmen, her iki sıkıntı biçimi netice itibariyle ferdin ruhsal dünyasındaki hoşnutsuzluğunu imleyen birer içe burkulma eğilimi vasfı taşır.

İç sıkıntı, bireyin ruhsal dünyasında ağırlıklı olarak olumsuz bazen de olumlu neticeler ortaya çıkarır. Kişiyi psikolojik acıya mahkûm etmesi ve öz benliğinin sosyal çevreyle olan münasebetini zedelemesi, can sıkıntısının negatif yönünü gösterirken ferdi kendi yüzeysel benliğiyle hesaplaşmaya doğru itmesi ise onun pozitif tarafını belirtir. Can sıkıntısına kapılan şahıs, etrafındakilere karşı istem dışı rahatsızlık duyarak onlara mesafeli yaklaşmayı tercih eder. Yaşama dair negatiflik, bireyler arası ilişkilerin anlamsızlığını ortaya çıkarır. Özne konumundaki bireyin öteki ile olan ilişkisinde derin bir kırılmanın yaşandığı bu ruh durumunda, benlik algısı da değişime uğrar. Bir insanın dışa yansıtmaya çalıştığı yapay benliği ve dıştan gizlediği asli benliği vardır. Yapay benlik, kişinin kendi dışındakilerle ilişki sağladığı benliktir. Asli benlik ise bireyin öz varlığıdır. Can sıkıntısının neden olmuş olduğu toplumsal kopuş, şahsı kendi ruh dünyasına doğru evirerek asli benliğiyle yüz yüze gelmesini sağlar. Böylelikle birey günlük yaşam içinde uygulamaya koyduğu yapay benliklerden ayrılarak öz benliğiyle baş başa kalır. "Can sıkıntısı, bazen kişiyi diğerlerinden, etrafındaki dünyadan ve gariptir ki kendinden bile ayırabilir. Aslında can sıkıntısı, kendine dişarıdan bakmak gibi alışılmadık ve nadir bir zorunlu olanak sağlar” (Toothey, 2014: 149). Toplumsal kopuş, bungunluğun menfi boyutuna karşılık gelirken kişinin reel yaşam pratiğinde gizlemeye çalıştığı kendi saf varlığıyla karşılaşması ise bu duygunun müspet yönüne işaret eder.

\section{12 EYLÜL DARBE DÖNEMI'NIN ROMANA YANSIYIȘI}

Cumhuriyet tarihinin kırılma noktalarından birini oluşturan 12 Eylül Darbesi, öncesi ve sonrasıyla romanlarda farklı dünya görüşlerine mensup yazarlarca işlenir. Bu eserlerde öncelikle sol ideolojiyle özdeşleşmiş “haksız düzen, sömürü” (Moran, 2014: 51) gibi politik ve toplumsal temalar etkisini yitirir, bunların yerine örgüt mensubu bireyin politik çalışmalarından kaynaklı uğradığı acılara ve sorunlara değinilir. Kaotik atmosferin varlığını güçlü şekilde hissettirdiği bu yapıtlarda idealist bireyin ideolojisini terk etmesi, mensubu olduğu politik oluşuma olumsuz eleştirilerde bulunması, insani dürtüleri ile örgütün kuralları arasında sıkışması, trajik sona maruz kalması ve halkın siyaset dışı kalma çabası ele alınır.

12 Eylül Dönemi’ni ele alan romanlarda birey devrimci kimliğini terk etmekle yetinmez, geçmişte sahip çıkıp bedeller ödediği bu kimliğe karşı kayıtsızlık içine girer. Pasifize olan romanların devrimci bireyi, gündelik yaşamın pratikleri arasında şahsi hayatını idame etme yoluna giderek ideolojik atmosferin dışına çıkar. “Gençliklerini ve davalarını 70’lerde yaşayan, olgunluk dönemlerini ise 80'lerin depolitize edilmiş yıllarında yaşayan kahramanlar hayata daha teslim olmuş, davadan daha çok uzaklaşmış bir profil ortaya koyarlar" (Coşkun, 2004: 534). Düşünce ve duygu dünyasında yaşanan bu köklü dönüşüm, geçmişi inkâr etmeye doğru bir seyir izler. Darbe öncesinde örgüt militanları olmalarından kaynaklı olarak toplumsal yaşamda etkin rol alan roman karakterleri, darbeden sonra içe kapanırlar ve aidiyet duygusuyla ilişkili oldukları organik yapılara dönük özeleştiri içine girerler. "Bu romanlarda 12 Eylül döneminin militanlarının kendi aralarında düştükleri çelişkiler sergilenir, roman kişilerine öz eleştiri yaptırılır” (Özer, 2011: 251). Genellikle sol gelenekle bağlantılı olan roman kişileri, başta örgüt-içi ilişkilerdeki despotik yönelim olmak üzere mutlak itaat anlayışına sert eleştirilerde bulunur.

Bireysel istemler ile örgütün katı kuralları arasındaki sıkışmışlık durumu, dönem romanlarında belirgin biçimde işlenir. İdeoloji yüklü politik oluşumlar içinde yıllarca mücadele eden anlatı karakterleri sevgi, cinsellik, çocuk doğurma gibi taleplerini ya kısık sesle dile getirir ya da hayallerinde yaşatmaya çalıșır. Örgütler tarafından zaaf olarak görülen ve politik hedeflerine ulaşmada engelleyici faktörler gözüyle yaklaşılan bu tarz insani dürtüler, roman kişilerini iç çatışmaya sürükler. "Aşkı ve cinselliği yasaklayan siyasal dayatmaların yarattığı karakterler 1980 döneminin politik örgütleri içinde bir engel olarak” (Balık, 2009: 2396) eserlerde yer alır. Yoğun politik atmosferde örgütleri tarafından dışlanmama adına bu tarz insani yönelimleri bastırma yoluna giden militanlar, darbeden sonra dağılan ve parçalanan politik oluşumları firsat bilerek bilinçaltlarına itmek zorunda kaldıkları arzularını gerçekleştirmeye çalışırlar.

Anlatı karakterlerinin trajediyle neticelenen sonları da dönem romanlarından önemli ölçüde yer alır. 1970’li yıllarda ülkenin politik atmosferinden etkilenerek sol ve sağ örgütlere katılan ve bu yapılarda etkin mücadele içine giren roman şahısları, 12 Eylül darbesiyle ya ülke içi ve dışında kaçak yaşama mahkûm olur, ya cezaevine girerek ağır işkencelerden geçirilir ya da öldürülür. Askeri idare tarafından ideolojik havayı soluyan kişiler üzerinde uygulanan fiziksel ve psikolojik baskı, bu şahıslarda yaşama dair memnuniyetsizlik halini doğurur. Hareket etme alanlarının daralması sonucu ortaya çıkan kısıtlanmışlık durumu da onların hayattan doyum alma olanağını ortadan kaldırır. Bunların neticesinde kasvetli bir ruh haline sürüklenerek dış dünyanın kaba gerçekleri karşısında yılgınlığa kapılırlar.

12 Eylül romanlarında, politik ve sosyal meselelere karşı ilgisiz bir duruş sergileyen halk kitlesinin varlığı söz konusudur. Özellikle darbenin gerçekleşmesinden sonra bu durum daha da belirgin bir hal alır. Dönemin aydınlarından biri olan Murat Belge'nin de belirtmiş olduğu gibi “12 Eylül günü başlayan dönemde birçok insanda genel sorunlara karşı bir kayıtsızlık ve umarsamazlık tavrı" (Belge, 2014: 115) ortaya çıkar. Siyasi faaliyetlere bulaşmakla egemen politik erk tarafından ağır cezai yaptırımlara maruz kalacağının farkında olan romanlardaki sosyal çevre, adeta vebadan kaçar gibi siyasi alandan uzak durmaya çalışır. Cunta yönetiminin örgüt militanlarına ve sempatizanlarına uyguladığı kıyıcı nitelikli uygulamalar, halkın gözünü 
korkutur ve onların içe çekilmesine yol açarak siyaset kurumuna karşı yabancılaşma içine girmesine neden olur. Böylece “yozlaşmış, temel değerlerinden habersiz, amaçsız bireylerin yetiştirilmesine zemin” (Özger, 2012: 96) hazırlanmış olur. Halkın çıkarı yerine kendi çıkarını savunan dönemin bu yeni insan tipi, sorumluluk alanı olarak sadece şahsi yaşamına odaklanır. Toplumsal değerlerin örselendiği dönemin reel yaşamında, bireysel arzuların tatmini hayatın asli ereği haline gelir.

\section{GECE DERSLERI, SESSIZ EV VE KUS DILINE ÖYKÜNEN ROMANLARINDA RUHSAL DARALMA HALİ}

12 Eylül Dönemi’ndeki negatif içerikli umumi atmosferin bireylerin ruhsal dünyasında yaratmış olduğu iç sıkıntı, Latife Tekin’in Gece Dersleri adlı romanında Gülfidan karakteri üzerinden ele alınır. Yazar üçüncü romanı olan bu eserinde, darbe öncesi yıllarda sol zihniyete sahip Sekreter Rüzgâr kod adlı Gülfidan'ın kapıldığı can sıkıntısını anlatı boyunca başarılı bir şekilde verir. Orhan Pamuk'un üç nesli tek mekânda buluşturduğu ve çoğul bakış açısıyla yazdı̆̆ı Sessiz Ev romanında ise can sıkıntısı anlatıcı pozisyonundaki karakterlerden biri olan Hasan'da görülür. İdeolojik kamplaşmanın bireyler arası gerginliği tırmandırdığı eserde, sağ görüşlü Hasan'ın sosyalist yapılara ve bedensel zevklere odaklanan kesime dönük huzursuzluğu iç monolog tekniğiyle yansıtılır. Ayşegül Devecioğlu'nun ilk romanı Kuş Diline Öykünen'de de can sıkıntısı etkili bir izlek konumundadır. Anlatının kadın karakteri Gülay, 12 Eylül Darbesi’nden sonra tutuklanarak cezaevine konur ve burada kaldığı süre zarfında resmi görevliler tarafından birkaç kez tecavüze uğrar. Hapishaneden çıktıktan sonra tinsel dünyasında travma izi bırakan bu olayı sık sık hatırlaması sonucu iç sıkıntıya uğrar. Yavuz ise, politik kaçak hayatı devam ettirme mecburiyetinde kaldığı için daimi bir huzursuzluk hâli içindedir.

\subsection{Askeri Cunta İdaresinden ve İllegal Örgüt Yapısından Kaynaklı Bungunluk}

12 Eylül Darbe Dönemi’nde farklı dünya görüşlerine mensup örgüt elemanları, bir yandan örgüt içi baskıdan dolayı diğer yandan da askeri vesayet altındaki devlet mekanizmasının kıyıcı niteliğinden ötürü iç daralma halini yoğun şekilde yaşamak zorunda kalır. Gece Dersleri'nin ana karakteri Gülfidan, iki taraflı baskıya maruz kalan kişilerden biri olarak dikkat çeker. Yazar Latife Tekin'in bireysel yaşamıyla ortak tarafları bulunan Gülfidan, Sekreter Rüzgâr takma ismiyle on sekiz yaşından itibaren sol menşeli örgüt içinde aktif biçimde görev almış militan bir kızdır. On yıl boyunca faaliyet yürüttüğü politik oluşumla bir türlü doku uyumunu sağlayamadığı için takma adını/örgüt hayatını bir türlü benimseyemez ve gerçek benliğini temsil eden öz ismini/örgüt dışı yaşamını özleyerek onu iç dünyasında diri tutmaya çalışır. "Gülfidan tamamen yok olmayı kabul etmez. ‘İllegalitenin masal yazıcısı' olarak Sekreter Rüzgâr'ın bedenine saklanır” (Parla, 2015: 220). Dili iyi kullanabilme becerisi ve aksiyoner kimliği sayesinde kısa süre içinde mensubu olduğu teşkilatta iyi bir konuma gelen Sekreter Rüzgâr, süreç içinde üyesi olduğu organik yapıyla çeşitli mevzularda çelişkiler yaşamaya başlar. Bireysel talepleriyle örgüt çıkarının çatışması, kendisiyle teşkilatın diğer elemanları arasında önce zihinsel daha sonra da duygusal zedelenmeyi ortaya çıkarır. Politik oluşumun ondan işçi olmasını ve çocuk doğurmamasını dilemesi karşısında ikilemde kalan Gülfidan, ruhsal sıkışmayı şiddetli biçimde duyumsayarak can sıkıntısına kapılır. "Ah hayatım hiç benim olmadın” (Tekin, 2012: 55) cümlesi, öz benliğinin istemlerini uzun süre boyunca yerine getirememenin yol açmış olduğu hüznü işaret eder. Özellikle örgütün üst düzey kadrosu tarafından kürtaja zorlanarak cinsel kimliğine yapılmak istenen müdahale, kendisinde bungunluğu tırmandırır.

Gülfidan, ideolojik faaliyetlerinden ötürü 12 Eylül Darbesi'nden sonra militarist darbeci erk tarafından takip edildiğini ve yakalanıp hapsedileceğini düşünerek daimi bir huzursuzluk içine girer. Devletin kolluk kuvvetleri tarafından gözaltına alınma endişesi, onu uzun süreliğine bir evde saklanma mecburiyetinde bırakır. Bedensel açıdan hareket etme olanağının sınırlandırılması ve günlük yaşam pratiğinin sekteye uğraması, bu genç kızda ruhsal gerilimi tırmandırarak iç daralmayı ortaya çıkarır. Maddesel varlığının devingen bir yapıya bürünmesinin devlet mekanizmasınca engellenmesi sonucu, dar sosyal çevresiyle de münasebeti en düşük seviyeye iner. İç sıkıntıyı hafifletmenin önemli saç ayaklarından biri olan sosyalleşmenin ortadan kalkması, onda bu rahatsız edici ruh halini aktif halde tutar. İnsanoğlu sıkıntısını birilerine anlatarak nispeten huzura kavuşmak ister. Ama Gülfidan, tutuklanıp çeşitli cezai yaptırımlara maruz kalmama adına, can sıkıntısını günlük yaşamının ayrılmaz bir parçası olarak yaşamak zorunda kalır.

Sessiz Ev'de örgüt baskısından kaynaklı olarak can sıkıntısına kapılan kişi, milliyetçi dürtülerle hareket eden lise öğrencisi Hasan'dır. Okul derslerinde başarısız olan ve sınıf tekrarına kalan Hasan, Cennethisar'daki ülkücü gençlere takılan idealist bir gençtir. Mustafa ve Serdar isimli arkadaşlarıyla duvarlara siyasi sloganlar yazan ve esnaftan haraç toplayan bu lise öğrencisi, sürekli arkadaşlarının ağır hakaretlerine maruz kaldığından can sıkıntısına kapılır. Milliyetçi gençlerin düzenleyecekleri etkinlik için davetiye dağıttıkları esnada, kendisi de milliyetçi görüşlere sahip bir esnafın iki davetiye istemesine sinirlenen Hasan, ona on davetiye uzatır. Bu durumdan rahatsız olan esnaf, Hasan'a "çakal” diye seslenir. Arkadaşları arasında dalga konusu olan bu hitap şekli, onda iç sıkıntıyı meydana getirir:

Bizi Cennethisar'dan çağırıp bu işi verdikleri için ben burada sizinleyim ve esnafla bir olup alay eden ve o kelimeyi söyleyip gülüşen sizlerle zaten konuşacak bir şeyim yok benim, susuyorum. Bir eczaneye girdik sustum, kasaba girdik sustum, bakkalda ve ondan sonraki nalburda ve kurukahveciyle kahvede de öyle sustum ve çarşı bitene kadar ben hiç konuşmadım (Pamuk, 2017: 30).

Hasan, sol görüşlü Nilgün'e beslediği romantik hislerden arkadaşlarının haberdar olması sonucu onlar tarafindan bir kez daha psikolojik baskı altına alınır. Plajda güneşlenen Nilgün'ü beklediği esnada Serdar'a yakalanır ve onun tarafından bu olay Cennethisar'daki ülkücü gençliğin lideri Mustafa'ya bildirilir. Bunu öğrenen Mustafa, büyük bir öfkeye kapılır ve Hasan’ı sorguya çekerek onu casuslukla itham eder. İdeolojik bağnazlığın yaşam tarzı haline dönüştüğü 12 Eylül Darbe Dönemi’nde, düşman kutupta yer alanların birbirlerine duygusal olarak yakınlık hissetmesi affedilemez bir suç olarak görülür. Davaya ihanet olarak kabul edilen bu durum, olayın muhatabı ile örgütün diğer üyeleri arasında radikal kopuşu hızlandırır. "Bir milliyetçi ya 
da parti militanı için hiçbir düşman karşı tarafa geçen ya da onu suçlamakta yeteri kadar ileri gitmeyen ‘içimizdeki düşman'dan daha aşağılık ve iğrenç değildir, uzlaşmacı bir tutum doğrudan doğruya düşmanlıktan çok daha şiddetle kınanır” (Bauman, 2016: 70). Nilgün'e âşık olmadığına örgüt arkadaşlarını inandırmak için yoğun bir gayret gösteren Hasan, onların inanmaz tutumları ve kendisini aşağılamaları karşısında ruh darlığı yaşar. "Terledim, başımı önüme eğip keşke şimdi burada olmasaydım, kimse bana karışamazdı; bahçeye çıkar, uzaklara giden sessiz gemilerin ürpertici lambalarını seyreder heyecanlanırdım" (Pamuk, 2017: 150). Örgüt içindeki bireylerin psikolojik tazyikine ara sıra maruz kalmasına rağmen yine de onlardan ayrılmayı göze alamayan Hasan, hayaller yoluyla can sıkıntısını dindirmeye çalışır. Bu düşlerde kendisini ülkücü hareketin başbuğu olarak görür ve Mustafa ile Serdar'ı kendisine muhtaç konumda bulunan kişiler olarak hayal eder.

Kuş Diline Öykünen isimli roman, 12 Eylül Darbesi’nden yaklaşık beş yıl geçmesine rağmen askeri idare güdümlü baskının örgüt üyeleri ve sempatizanları üzerindeki etkisini yitirmeden devam ettiğini gösteren bir eserdir. Darbeden önce Marksist öğretiyi benimsemiş politik bir yapının askeri kanadında yer almış ve birçok eylemde bulunmuş Yavuz kod adlı Caner Yılmaz, 12 Eylül'den sonra gözaltına alınma olasılığından ötürü yurt içinde kaçak bir yaşama mahkûm olur. "İnsanoğlunun varoluş sürecinde kendi yapısında saklı kalan" (Eronat, 2010: 219) kaçış duygusu, sıkışma anında önemli bir savunma mekanizması işlevi taşır. Ailesiyle ve örgütteki arkadaşlarıyla münasebetini asgari seviyeye indiren Yavuz, uzun süre boyunca kimseyle iletişime geçmeden bir evde tek başına kalır. Burada bulunduğu süre zarfında güvenlik güçleri tarafından baskına uğrama endişesi onda can sıkıntısını etkin bir duygu olarak ortaya çıkarır. "Günlerini, gecelerini geçirdiği korkunç bir ölüm hücresinden başka bir şey değildi bu ev” (Devecioğlu, 2013: 103). 1980’lerin kaotik atmosferinde daraltılmış mekâna sıkışmış ve özel yaşam kurması imkânsız hale gelmiş Yavuz, fiziksel ve ruhsal kısıtlanmışlıktan kurtulmak amacıyla yurt dışına kaçma planları yapar. Ailesinden aldığı parayla pasaport işini halletmesine rağmen bir yandan iletişime geçeceği kişilere dönük beslediği güvensizlik öte yandan çatışmaya girip kendini feda ederek geleceğe iz bırakma adına bu kararını fiili hayata aktaramaz.

\section{2. İdeal ve Realite Çatışmasının Doğurduğu Bungunluk}

Mevcut durumdan daha iyi bir sosyo-politik tasarım meydana getirmek amacıyla çeşitli ideolojilere bağlanan bireyler, dış dünyanın kaba gerçekleriyle idealleri arasındaki çelişkiyi gördükçe huzursuzluğa kapılır. Zihinde mükemmel bir forma büründürülen dünya görüşleri, güncel yaşamın karmaşı ilişkiler ağı ve insan tabiatındaki zaaflar neticesinde arzulanan düzeye hiçbir zaman erişemez. Latife Tekin'in otobiyografik romanı Gece Dersleri'nin başkişisi Gülfidan, sosyalist ideolojinin yaratmak istediği insan profiliyle reel yaşamın devrimci kadın bireyi arasındaki uçurumun derinliğini gözlemleyerek huzursuz olur. $\mathrm{Bu}$ kadınların kongredeki tebrik mesajını dinlemeden baklavaya yönelmeleri, gazinolarda görev almaları, makyaj malzemelerini almaları ve satmaları Gülfidan'ı en fazla rahatsız eden mevzulardır. O, eleştirilerinin yetkili kişiler tarafından kabul edilmemesi ve gereksiz görülmesi karşısında ruhsal bakımdan daralma yaşar. "Yüce sınıfımız için, kendi düşlerine tutulan insanların çektiği acıyı, reddedilmenin yüreklerinde yaktığı ateşi düşündüm” (Tekin, 2012: 89). Hayallerinde inşa ettiği sosyalist kimlikli birey tipinin pratik yaşam alanında somutlaşmaması, onun mücadeleye dönük inancını olumsuz yönde etkiler ve süreç içinde mensubu olduğu politik oluşumdan ayrılarak devrimci mazisine sırtını dönmesine sebep olur. "Ütopyalar yıkılırken, romanın içine giren birey de bir devrimci olarak geçmişini terk ediş sırasında kendini hiçleme sanrısına" (Gümüş, 1990: 10) kapılır. On yıl aktif biçimde mücadele ettiği sol menşeli örgütten kopuşun yol açtığı boşluk duygusu, Gülfidan’ı anne kucağına ve masumiyetle saflığın yaşandığı çocukluk yıllarına götürür. Hayali nitelikteki bu sığınaklar onun yaşama tutunmasına, bireysel varoluşuna mânâ katmasına yardımcı olur.

Ülkücü hareket içinde aktif rol alan Sessiz Ev romanındaki Hasan, milliyetçi kimliğin kendisine yüklemiş olduğu dava adamı bilinciyle eğlence kültürünü yaşam tarzı haline getiren insanlardan rahatsızlık duyar. Turistik bir yerleşim yeri olan Cennethisar'da ikamet eden kişilerin plaja giderek duyusal zevk peşinde koşması, politik idealler peşinde koşan bu lise öğrencisinin canını sıkar. Aynı ortamı paylaşmak zorunda kaldığı bu kişilerin haz odaklı günlük yaşamlarına dönük memnuniyetsizliğini iç monolog tekniği aracılığıyla şu şekilde dile getirir. " Utanmıyor musunuz cehennemden, vicdanınız da mı yok; yoz, sefil, ahlaksız yaratıklar, nasıl oluyor da kendi keyfinizden ve dükkânınız ve fabrikanızın kârından başka hiçbir şey düşünmeden yaşayabiliyorsunuz, anlamıyorum ama artık göstereceğim size" (Pamuk, 2017: 129). Milliyetçi fikirlerle zihin dünyası şekillendiği için yaşama dönük okumalarını o perspektiften yapan Hasan'ın canını sıkan diğer bir durum ise fabrikadaki işçilerin yaptıkları grevlerdir. Çalışanların iş bıraktıkları bu tarz eylemleri genellikle sol fraksiyonlu yapıların organize etmesi, onda iç sıkıntıyı harekete geçirir.

Ayşegül Devecioğlu'nun Kuş Diline Öykünen adlı romanının odak şahsı konumunda bulunan Gülay, 12 Eylül'den sonra sosyalist imgelerin, kavramların reel yaşamdaki görünürlüğünü yitirdiğini gözlemleyerek psikolojik daralma yaşar. 12 Eylül 1980'den önce telefon santralinde memur olarak çalışan Gülay, hem sol kökenli bir aileden gelmesi hem de çalıştı̆̆ işyerinde solun ağır basmasından kaynaklı olarak Marksist ideolojiyi benimser. Darbeden yaklaşık iki yıl önce üyesi olduğu sol örgütün bazı haberleşmelerini üstlenerek aktif rol alır. Darbeyle birlikte yakalanır ve cezaevinde çeşitli işkencelere maruz kalır. Buradan çıktıktan sonra örgütsel hiçbir faaliyete girişmez ve bireysel yaşamına odaklanır. Teorik düzlemde solun değerler dizgesine olan inancını yitirmeyen Gülay, sosyal yaşam alanında toplumun bu değerlere dönük umursamazlığına şahit olarak iç sıkıntıya uğrar. Ablasının çocuğu Devrim’e seslenmesine rağmen parkta bulunan kişilerin ilgisizliği, Darbe yönetiminin solun ideolojik belleğini halkın günlük yaşamının dışına çıkarma hususunda başarılı olduğunu gösterir:

Zaman... Zamanı anlamak, diye düşündü Gülay, bu yabancı, bu zalim zamanı anlamak; kaderle baş edebilmenin tek yolu belki. Bu düşüncenin üstünde zihni halsizce oyalandı. Sonra kalktı, belli belirsiz bir umutla gözlerini parkta dolaştırd1. (...) Biraz ötesinde, kendinden bir-iki yaş küçük bir oğlanla oynayan çocuğu gördü. Devrim! diye seslendi. Birden, ilk kez, bu kadar yüksek sesle Çocuğun adını söylediğini ayrımsadı. İsim, kaçak bir mahkûm gibi fırlayıvermişti 
ağzından. Gayri ihtiyari çevresine bakındı. Sonra, alışılmadık, tuhaf bir şey yapıyormuş gibi, söyleyip söyleyemeyeceğinden emin olmadan, bir kez daha bağırdı. Kimse ilgilenmiyordu. Kimse onlara bakmıyordu.

Duymamışlardı bile (Devecioğlu, 2013: 220).

\subsection{Travmatik Olaylardan Kaynaklı Bungunluk}

Ferdin deneyimlediği ağır vakalar, can sıkıntısının belirmesinde önemli bir göstergedir. Her bir fert yaşamının belli dönemlerinde hem bedensel hem de ruhsal açıdan çeşitli travmalarla karşı karşıya kalabilir. Ağır kazalar, cinsel istismar, romantik/cinsel aldatılma, savaş, doğal afetler, işkence, yakın birinin ölümü gibi sarsıcı durumlar travmanın ortaya çıkmasında belli başlı unsurlardır. Bu tip durumlara maruz kalma, bireyin psikolojisinde kalıcı hasarlar meydana getirir. Günlük yaşamın hareketli anlarında bilinçaltına itilebilecek böyle yaşantılar, umulmadık zamanlarda ortaya çıkarak bireyin hayata dönük tüm enerjisini felce uğratabilir. Travmanın boyutu ve ona maruz kalan kişinin ruhsal durumu, sarsıntının etki düzeyini belirlemede önemli unsurlardır.

Gece Dersleri romanının merkezi kişisi Gülfidan, aynı ideolojik kimliği taşıdığı bir arkadaşının ölümünden kaynaklı olarak iç sıkıntıya maruz kalır. O, 12 Eylül Darbesi'nden sonra güvenlik güçlerince yakalanan ve çeşitli işkencelere maruz kaldıktan sonra komaya girip ölen bu dostunun annesini mensubu olduğu örgütün bazı üyeleriyle ziyaret eder. Arkadaş grubu tarafindan ölünün özel eşyalarını sergilemek için annesini ikna etme görevi kendisine verilen Gülfidan, zihniyet ortaklığı taşıdığı dostunun odasına girdiği zaman tinsel açıdan ruhsal daralma içine girer. "Bezgin başımı geriye attım. Sanki ta uzaklara düşebilirmiş gibi. Tavanda onun coşkulu çığlığının lekelerini gördüm. Burkuldum ve sesimin titremelerle bozulmasına firsat vermeden soluğumu tutup kendimi susturdum" (Tekin, 2012: 135). Birçok deneyim yaşadı̆̆ı ve yakın münasebet halinde bulunduğu birinin reel yaşamın dışına çıkması, Gülfidan'ın ruhsal dünyasında travmatik bir etki oluşturur. Uzun süre boyunca yaşamsal fonksiyonların devre dışı kaldığı bu trajik olayın izini üzerinden atamaz.

Kuş Diline Öykünen'de, Alevi kökenli ve sol sempatizanı olan Gülay’ın ailesi, 12 Eylül Darbesi’nden sonra yaşadıkları travma düzeyi yüksek olaylardan kaynaklı olarak trajik bir görünüme bürünür. Ailenin büyük kızı Sevim'in kocası Mustafa cezaevine girerken, iki yaşındaki oğlu Devrim iltihaplanma sonucu bir gözünü kaybeder. Evin ortanca kızı Gülay ise yaklaşık üç yıl kaldığı hapishanede cezaevi görevlileri tarafından tecavüze uğrar. Negatif anıların bedensel ve ruhsal yaralar bıraktığı ev, netice itibariyle "çaresiz hastaların, hiçbiri kişisel olmayan belli belirsiz izler, şöyle bir karıştırılıp atılmış dergiler, sıkıntıdan bin bir şekle sokulmuş kâğıt parçaları, sönmüş sigaralar, bıraktıkları o uğursuz bekleme odalarına, görenlerin hiç yoktan hüzünlendiği 1ssız istasyonlara dön(er)" (Devecioğlu, 2013: 93). Özellikle Gülay’ın tecavüze uğraması sonucu bekâretini kaybetmesi, ailenin iç daralmayı yoğun biçimde hissetmesine yol açar. Gülay da bu trajik yaşantıdan dolayı dar sosyal çevresi tarafından anlamlı bakışlarla ve imâlı sözlerle karşılaştıkça huzursuzluğa kapılır. Sosyal çevresindeki erkeklerin kendisine dönük cinselliği çağrıştıracak tutumlar içinde bulunması da onda cinsel işkence anılarını depreştirdiği için can sıkıntısını meydana getirir:

Erkeklerle karşılaşınca kızarıp bozarmalarını, Çetin'in eziyetlerini, Selim karşısındaki çaresizliğini, otobüsteki çocuğun bacak arasına bakmamak için nasıl çaba gösterdiğini anımsıyordu. Bir erkekle yalnız kaldığı ya da karşı karşıya oturduğunda hep aynı şey oluyordu. Gözünü kaçırmaya çalışsa da eninde sonunda aynı şeyi yapıyordu. Farkına varacaklar diye kahroluyordu. Yara almak... Kadın olarak yara almak... Bu yaralar, bunca derin, bunca cerahatli yaralar iyileşir miydi (Devecioğlu, 2013: 62).

\section{SONUÇ}

12 Eylül Darbe Dönemi’ni ele alan Gece Dersleri, Sessiz Ev ve Kuş Diline Öykünen isimli yapıtlarda, içe yönelme eğilimlerinden biri olan can sıkıntısının bariz biçimde etkileri söz konusudur. Anlatılardaki birinci dereceden önemli kişiler üzerinde umumi bir ruh haleti olarak görülen bu negatif içerikli duygu, bireylerin yaşama dönük memnuniyetsizliğini gösterir. Dönemin kaotik siyasi atmosferinden kaynaklı olarak görünürlüğünü hissettiren bungunluk durumu, fertlerin devingen yaşam ağına etkin tarzda katılımını engelleyici pozisyon özelliği taşır.

Askeri cunta yönetimi ve örgütler tarafından uygulanan fiziksel ve psikolojik baskı, roman karakterlerinin iç sıkıntıyı yaşamasına neden olur. Gece Dersleri’nin merkezi kişisi Gülfidan, 12 Eylül darbesinden önce aktif biçimde mücadele yürüttüğü sol menşeli örgütün kendisinden devrim gerçekleşen kadar işçi olmasını ve bebeğini aldırmasını istemesi karşısında ruhsal daralma içine girer. Darbeden sonra ise militarist politik erk tarafından arandığı için gerilir. Ülkücü hareket içerisinde bulunan Sessiz Ev'deki Hasan ise örgütteki arkadaşlarının kendisini aşağılamaları karşısında huzursuz olur. Tecrübe ve yaş olarak onların gerisinde kaldığı için hakaretlerine ses çıkaracak gücü kendisinde bulamaz. Kuş Diline Öykünen yapıtındaki Caner Yılmaz, darbeden önce sol hareket adına birçok öldürme eylemine karıştığından cunta yönetimince arananlar listesindedir. Yurt içinde politik kaçak oluşu ve her an yakalanma olasılığı onda can sıkıntısını tetikler.

Romanlardaki temel karakterler, sosyo-politik açıdan ideal bir dünya düzeni kurma amacıyla yöneldikleri ideolojilerinin dış dünyanın gerçekleriyle çatışması neticesinde can sıkıntısına kapılır. Sekreter Rüzgâr kod adlı Gülfidan, örgütteki işçi kadınların zihinsel yetkinliğe ve ruhsal olgunluğa sahip olmadıklarını görerek hayal kırıklığına uğrar. Bu duruma dönük yaptığ eleştirilerin yapının üst kadrosu tarafından kabul edilmemesi ondaki gerilimli ruh halini tırmandırır. Sessiz. Ev'in Türk milliyetçisi karakteri Hasan, eğlence kültürünü yaşam tarzı haline getiren kesimden ve sol yapıların organize ettiği işçilerden memnuniyetsizlik duyar. Kuş Diline Öykünen'in ana kişisi Gülay ise darbeden sonra halkın solun değerler manzumesine karşı kayıtsız duruşu karşısında huzursuz olur. 
12 Eylül darbesini gerçekleştiren askeri yönetimin iktidarda olduğu süre zarfında muhalif kesimlere karşı kıyıcı nitelikteki uygulamaları, romanlardaki ideolojik bireylerin iç sıkıntıya kapılmasına yol açar. Gülfidan, örgütteki bir arkadaşının ağır işkencelerden geçirildikten sonra ölmesi karşısında psikolojik daralmaya uğrar. Kuş Diline Öykünen'in kadın karakteri Gülay ve ailesi, darbeden sonra ailece uğradıkları felaketler neticesinde iç sıkıntı yaşar. Gülay çeşitli işkencelerden geçerken, eniştesi Mustafa cezaevine girer, yeğeni Devrim ise bir gözünü kaybeder. Travma boyutu yüksek bu tip olaylar, eve kasvetli bir hava yükler.

Sanatçıların aynı sosyo-politik ortamı paylaşan roman karakterlerinde can sıkıntısının meydana gelişini benzer gerekçelerle dile getirmeye çalışması, dönemin ruhuna uygunluk gösterir. Ayrıca anlatı karakterlerinin farklı sosyal tabakalara mensup olmalarına ve birbirleriyle çatışan değerler manzumesini taşımalarına rağmen iç sıkıntıyı ortak duygu olarak yaşamaları, dönemin genel psikolojik durumunu ele verir.

\section{KAYNAKÇA}

Ahmad, F. (2017). Modern Türkiye’nin Oluşumu. Çev: Yavuz Alogan, Ankara: Kaynak Yayınları.

Balık, M. (2009). Türk Romanında 12 Eylül Darbesi. Turkish Studies International Periodical For the Languages, Literature and History of Turkish or Turkic Volume 4 /1-II Winter.

Bauman, Z. (2016). Sosyolojik Düşünmek. Çev: Abdullah Yılmaz, İstanbul: Ayrıntı Yayınları.

Belge, M. (2014). “Politik Roman Üstüne”. Edebiyat Üstüne Yazılar. İstanbul: İletişim Yayınları.

Bulut, F. (2011). 68 Kuşağı Gençlik Olaylarının Uluslararası Boyutu ve Türkiye’de 68 Kuşağına Göre Atatürk ve Atatürkçülük Anlayışı. ÇTTAD, XI/23, 123-149

Coşkun, S. (2004). “İki Eserde İki Siyasi Dönem: Ya Tahammül Ya Sefer ve Mektup Aşkları. Hece Hayat, Edebiyat, Siyaset Özel Saylst. 90/91/92, 531-535.

Devecioğlu, A. (2013). Kuş Diline Öykünen. İstanbul: Metis Yayınları.

Eronat, K. (2010). Adalet A 乌̆aoğlu İnsan ve Eser. Ankara: Maya Akademi Yayınları.

Gümüş, S. (1990). Bir Döneme Teğet Kalan Roman. Varlık Dergisi, 999, 9-11.

Kışlalı, A. T.(1974). Öğrenci Ayaklanmaları. Ankara: Bilgi Yayınları.

Özer, H. (2011). 12 Eylül 1980 Darbesinin Türk Romanına Yansıması. (Yayınlanmamış Doktora Tezi), İstanbul: İstanbul Üniversitesi, Sosyal Bilimler Enstitüsü.

Özger, M. (2012). Türk Romanında 12 Eylül. İstanbul: Kaknüs Yayınları.

Moran B. (2014). “12 Eylül ve Yenilikçi Roman”. Türk Romanına Eleştirel Bir Bakış3. İstanbul: İletişim Yayınları.

Pamuk, O. (2017). Sessiz Ev. İstanbul: Yapı Kredi Yayınları.

Parla, J. (2015). Türk Romanında Yazar ve Başkalaşım. İstanbul: İletişim Yayınları.

Svendsen, H. FR. L. (2020). Sikıntının Felsefesi. İstanbul: Bağlam Yayıncılık.

Tekin, L.(2012). Gece Dersleri. İstanbul: İletişim Yayınları.

Toohey, P. (2014). Can Sıkıntısının Eğlenceli Tarihi. İstanbul: Doğan Egomant Yayıncılık.

Zürcher, E. J. (2018). Modernleşen Türkiye'nin Tarihi. İstanbul: İletişim Yayınları. 